\title{
The Wilderness Act and Fish Stocking: An Overview of Legislation, Judicial Interpretation, and Agency Implementation
}

\author{
Peter Landres, ${ }^{1 *}$ Shannon Meyer, ${ }^{1}$ and Sue Matthews ${ }^{2}$
}

\begin{abstract}
${ }^{1}$ Aldo Leopold Wilderness Research Institute, Rocky Mountain Research Station, United States Department of Agriculture-Forest Service, Missoula, Montana 59807, USA; and ${ }^{2}$ Arthur Carhart National Wilderness Training Center, United States Department of the Interior-Fish and Wildlife Service, Missoula, Montana 59812, USA
\end{abstract}

\begin{abstract}
Many high-elevation lakes in designated wilderness are stocked with native and nonnative fish by state fish and game agencies to provide recreational fishing opportunities. In several areas, this practice has become controversial with state wildlife managers who support historical recreational use of wilderness, federal wilderness managers who assert that stocking compromises some of the ecological and social values of wilderness, and different public groups that support one or the other position. Herein we examine this controversy from the perspective of the 1964 Wilderness Act, its judicial interpretation, the policies of the federal agencies, and formal agreements between federal and state agencies. Although some state stocking programs restore native fish populations, other programs may
\end{abstract}

\section{INTRODUCTION}

The Wilderness Act of 1964 designated 9.1 million acres of United States Department of Agriculture (USDA) Forest Service land to be administered for two broad goals: use and enjoyment as wilderness, and protection and preservation as wilderness. Today there are over 104 million acres of federally

Received 28 March 2000; Accepted 16 August 2000.

The views expressed in this paper are solely those of the authors and do not represent the official policy or views of the US Forest Service or the US Fish and Wildlife service.

*Corresponding author; e-mail: plandres@fs.fed.us compromise some of the ecological and social values of wilderness areas. Further, although current federal regulations recognize state authority for fish stocking, judicial interpretation gives federal agencies the authority for direct involvement in decisions regarding fish stocking in wilderness. Where there are differences of opinion between state and federal managers, this judicial interpretation strongly points to the need for improved cooperation, communication, and coordination between state wildlife managers and federal wilderness managers to balance recreational fishing opportunities and other wildlife management activities with wilderness values.

Key words: wilderness; fish stocking; federal agencies; amphibians; federal policies; case law.

designated wilderness administered by the Forest Service (FS) and the United States Department of the Interior (USDI) Bureau of Land Management (BLM), Fish and Wildlife Service (FWS) and the National Park Service (NPS). Within the conterminous United States, nearly $91 \%$ of the National Wilderness Preservation System is in the western states (Landres and Meyer 1998), and much of this is in high-elevation coniferous forests and alpine ecosystems (Loomis and Echohawk 1999). In these high-elevation lakes, as well as in wilderness lakes and streams throughout the United States, state fish and game departments routinely stock native and 
nonnative fish for recreational fishing opportunities. Although in many areas, state and federal managers work together closely to restore and maintain populations of native fish, stocking is increasingly being questioned by federal wilderness and fisheries managers who are concerned about the effects of stocked fish on the biological diversity of native species (especially amphibians) and the social values associated with wilderness. Adding significantly to this debate between federal and state managers, Bahls (1992) found that more than $95 \%$ of nearly 16,000 high-elevation western lakes were historically fishless, raising serious questions about the appropriateness of continued fish stocking in these wilderness lakes (Murray 1994; Duff 1995; Carter 1996). This controversy over fish stocking has been further amplified by a longstanding debate over state vs federal authority for managing wildlife populations in wilderness areas.

The purpose of this paper is to provide an overview of the 1964 Wilderness Act, its judicial interpretation, related federal regulations and policies, and interagency agreements that affect federal and state interactions concerning the management of fish-stocking practices in wilderness areas. We first examine the values and purposes of wilderness; then, within this context, we briefly discuss the range of potential effects of fish stocking on wilderness. Next, we examine the jurisdictional debate between the states and federal government as reflected in Supreme Court decisions. Finally, we look at how this interpretation is reflected in the regulations, policies, and agreements of the four federal agencies that manage wilderness.

\section{IMPLICATIONS OF THE 1964 WiLDERNESS ACT}

Although the Wilderness Act of 1964 (Public Law 88-577) does not explicitly mention fish stocking, two parts of the act are relevant to this debate: the definition of wilderness, and interaction between state and federal authorities. Wilderness is defined in section 2(c) as "an area where the earth and its community of life are untrammeled by man." Later in this same section, it is further defined as "undeveloped Federal land retaining its primeval character and influence... which is protected and managed so as to preserve its natural conditions." This legislative definition raises two fundamental values of wilderness-wildness and naturalness (Aplet 1999; Cole 2000). Both wildness and naturalness are highly valued in our society (Manning and Valliere 1966; Cordell and others 1998), and understanding these values allows a deeper analysis of the effect of fish stocking on "the enduring benefits of wilderness" (Wilderness Act, section 2(a)).

Wildness is defined in Webster's Collegiate Dictionary as untrammeled or unrestrained, uncontrolled, self-willed, or free. Howard Zahniser, chief author of the Wilderness Act, testified before a committee of the New York State legislature in 1953 that "We must always remember that the essential quality of the wilderness is its wildness" (Zahniser 1992). Further clarifying his use of the terms "wildness" and "untrammeled," Zahniser (1956) wrote "there is in our planning a need also to secure the preservation of some areas that are so managed as to be left unmanaged-areas that are undeveloped by man's mechanical tools and in every way unmodified by his civilization." Wildness confers personal benefits of primitive and unconfined recreation, as well as substantial therapeutic and spiritual benefits (Dawson and others 1998). Larger societal benefits from wildness include the value of unmanipulated lands that will be inherited by future generations and the humility and sense of restraint that comes from leaving some lands unmanipulated (Rolston 1994). Also, in wild landscapes, the process of evolution is relatively unfettered by human manipulation (Landres 1992).

Naturalness may be defined as the native compositions, patterns, and processes of an area (Landres and others 1999). Naturalness confers both social and ecological value. For example, the scenic beauty derived from natural vistas provides societal benefits, including economic gain to local communities from recreationists and outfitters (Payne and others 1992), as well as therapeutic and cultural values. Ecological value comes from the educational and scientific understanding derived from natural systems. An important biological benefit of naturalness is the broad protection of uncharismatic fauna, such as small or larval and immature life forms not seen by typical wilderness visitors, and the landscape-scale protection that allows ecological processes such as fire and the movement of individuals across a landscape.

Although we discuss wildness and naturalness as distinct from one another here, in some cases this distinction blurs. For example, the scenic beauty of natural areas derives from these areas being both wild (or unmanipulated) and natural. In such cases, wildness and naturalness are not mutually exclusive.

On interactions between state and federal agencies, the Wilderness Act states: "Nothing in this Act shall be construed as affecting the jurisdiction or responsibilities of the several States with respect to wildlife and fish in the national forests" (section 
$4(d)(8))$. This clause has been the subject of considerable debate, with state advocates claiming that this clause supports their traditional view of exclusive rights to manage wildlife (Hoover 1978). Coggins and Ward (1981) assert that this clause simply maintains the status quo and was intended to be neither pro federal nor pro state. While the language of the Wilderness Act is central to this debate, the agencies that manage wilderness are also bound by the organic acts that established them, other land management statutes, and wildlife management laws.

\section{EFFECTS OF Fish STOCKING ON WILDERNESS}

Recreational fishing is widely regarded as a traditional and important use of wilderness. The artificial stocking of fish in protected areas was once strongly supported by conservation organizations (Schoenfeld and Hendee 1978) to provide recreational opportunities and to help populations of threatened and endangered fish. Recently, however, the stocking of nonnative species and the stocking of historically fishless lakes have become controversial because of changing societal values regarding recreation and the protection of biological diversity (Duff 1995). For example, in a recent national survey of public attitudes toward wilderness, nearly $80 \%$ of the respondents said that protecting water quality and wildlife habitat was very important; by contrast, only 50\% stated that recreational opportunities were very important (Cordell and others 1998). Furthermore, fish stocking is now known to compromise the naturalness of aquatic ecosystems in wilderness areas in direct and indirect ways. These ecological impacts have been reviewed by Liss and Larson (1991), Liss and others (1999), and Hoffman and Pilliod (1999), and will be considered in other papers in this volume.

In contrast to the impact of fish stocking on the naturalness of aquatic systems in wilderness, the effects of stocking programs on wildness have not been widely discussed and are therefore reviewed briefly here. Many people view wilderness as the one place in our increasingly human-dominated world that is specifically designated to be left alone and not manipulated for human desires (Turner 1996). In contrast, Janzen (1998) contends that ultimately all wildlands will become "gardenified." The conspicuous and intensive action of stocking fish to create opportunities for recreational fishing compromises this wildness by directly manipulating the wilderness. Helicopters and airplanes are the most common means for planting fish in wilderness lakes. Even if they do not land, they violate the spirit of the Wilderness Act and its prohibition against motorized vehicles and any form of mechanical transport. Aerial stocking also significantly degrades the primitive recreation experience by disrupting the solitude and quiet that most wilderness visitors seek. Wilderness experiences may also be compromised by the increase in the number of anglers that will be attracted to stocked lakes. Finally, the introduction of fish as a top predator significantly alters natural selection pressures within the aquatic ecosystem, potentially leading to different evolutionary trajectories and severely compromising a fundamental aspect of wildness.

\section{JUDICIAL INTERPRETATION}

There is a rich and complex body of law and judicial interpretation that bears on wildlife (Bean and Rowland 1997). We will review this material selectively as it relates to fish stocking in wilderness. At the heart of the controversy over fish stocking in wilderness areas is a jurisdictional debate between state and federal agencies (Gottschalk 1978; Coggins and Ward 1981; Matthews 1986; Buono 1997) that stems from different interpretations of the Constitution. In general, the states argue that wildlife management is a state prerogative supported by the 10th Amendment to the Constitution, the "police powers" clause. This clause asserts: "The powers not delegated to the United States by the Constitution, nor prohibited by it to the States, are reserved to the States respectively, or to the people." The states argue that because the power to regulate wildlife was not expressly delegated to the federal government, or forbidden to the states, it is retained by the states.

This tradition of wildlife ownership has its origins in feudal Europe. Having no specific owner, wild animals were considered to be the common property of all citizens and subject to government control. In England, unallotted lands were considered the "royal forest," and only the king could grant permission to hunt on them. Over time, this control was transferred from the Crown to the English parliament. The colonists brought this tradition of wildlife management to North America (Aderhold 1979). With the separation of the Colonies from the British Empire, the authority for wildlife management passed from parliament to the states. The US Supreme Court reinforced this concept in 1842, writing that "the powers of sovereignty, [and] the prerogatives and regalities" of the English Crown concerning wildlife had become vested in the states (Coggins 1980). At the same time, the Court held 
that the rights of the states were "subject. . to the rights since surrendered by the constitution to the general government" leaving questions about respective state and federal powers unanswered (Bean 1978).

The federal government's jurisdictional claim to wildlife management rests on four constitutional clauses. The property clause of the Constitution (US Constitution, art. 4, sec. 3, cl. 2) gives Congress the power to "make all needful Rules and Regulations respecting the Territory or other property belonging to the United States" and allows Congress to enact wildlife management laws for federal lands. The treaty clause (US Constitution, art. 1, sec. 10) reserves to the federal government the right to engage in treaties and has been used to protect wildlife from the pressures of international commerce. The commerce clause (US Constitution, art. 1, sec. 8, cl. 3) gives Congress the sole power to regulate commerce between states and has been used to strike down state-imposed restrictions on nonresident hunters and the exportation of game across state boundaries. Finally, the supremacy clause (US Constitution, art. 6, cl. 2) asserts that federal law supercedes state law when there are conflicts between the two.

During the second half of the 19th century, the doctrine of state wildlife ownership evolved through a series of cases in the Supreme Court dealing with the management of marketable fish and game (Coggins 1980). The most influential of these early cases is Geer v. Connecticut (1896), which dealt with the transportation of wild fowl over state lines. Geer held that the states owned the wild animals within their borders and could strictly regulate their management and harvest. According to the Geer Court, "the right to preserve game flows from the undoubted existence in the State of a police power." Although this statement is often quoted by state advocates, it is followed by the qualification that this power reaches only "in so far as its exercise may not be incompatible with, or restrained by, the rights conveyed to the Federal government by the Constitution" (Geer 1896). The Geer decision supported the view that the states owned all resident wildlife, but at the time there were no conflicting federal wildlife laws (Coggins 1980).

Federal wildlife management authority emerged through several Supreme Court cases. In 1918, Congress passed the Migratory Bird Treaty Act governing the taking of migratory birds both on and off federal lands. This act was upheld by the Supreme Court (Missouri v. Holland 1920) as a constitutionally valid exercise of the treaty powers. The Court recognized that "No doubt it is true that as between a State and its inhabitants the State may regulate the killing and sale of [wildlife], but it does not follow that its authority is exclusive of paramount powers." Without refuting the states' traditional wildlife management role, the Court acknowledged Congress's constitutional right to enact wildlife management legislation. Since the decision of this Court, nearly every conflict between state authority and federal mandate has been settled in favor of the federal government (Bean 1978).

Federal authority was further bolstered by the Supreme Court ruling affirming the Forest Service's ability to regulate deer populations on the Kaibab National Forest in Arizona (Hunt v. United States 1928). After years of predator suppression, deer populations on the Kaibab plateau had reached crisis numbers and forage was severely depleted. Thousands of deer were dying of starvation as a result of overbrowsing. After attempts to relocate animals failed, the Forest Service began killing deer to ease the pressure on forage. The State of Arizona challenged the federal agency's right to kill these animals without a state hunting permit. The United States filed suit to prevent further obstruction of its management program (Hunt v. United States 1928).

The state of Arizona argued that it was the sole owner of the wildlife inside its borders and federal efforts to control deer populations violated state game laws. The Supreme Court rejected this argument because the federal government retains the right of a property owner to protect its lands. In the Court's opinion, "there can be no doubt of the right of the government of the United States to do whatever is necessary for it to do upon its own property to protect it from the depredations complained of [using] means and methods of its own selection" (Hunt v. United States 1928). This important ruling laid the groundwork for successive cases supporting the federal government's authority over wildlife on federal land.

The Geer decision was dealt another substantial blow in 1976 by the unanimous Supreme Court decision in Kleppe v. New Mexico. In 1971, Congress passed the Wild Free-Roaming Horses and Burros Act to protect these animals from "capture, branding, harassment, or death." The New Mexico Livestock Board claimed the federal government did not have the power to control these animals unless they were items in interstate commerce or causing damage to the public lands. In February 1974, the board rounded up and sold 19 unbranded burros from Bureau of Land Management (BLM) land. When the BLM demanded the animals' return, the state 
filed suit claiming that the Wild Free-Roaming Horses and Burros Act was unconstitutional.

Although the lower court found for the state, the Supreme Court unanimously reversed this decision. It wrote that the "'complete power' that Congress has over public lands necessarily includes the power to regulate and protect the wildlife living there" (Kleppe v. New Mexico 1976). In addition, the Supreme Court said that Congress may enact legislation governing federal lands pursuant to the property clause and "when Congress so acts, federal legislation necessarily overrides conflicting state laws under the supremacy clause" (Kleppe v. New Mexico 1976).

In 1979, the Supreme Court resoundingly dismissed the Geer decision in Hughes v. Oklahoma (1979), rejecting the earlier case's "19th Century legal fiction of state ownership" of wildlife. In the Court's view, this "fiction" had "been eroded to the point of virtual extinction in cases involving regulation of wild animals" (Hughes v. Oklahoma 1979). With the fall of Geer, the last precedential impediment to the federal government's wildlife management authority was removed.

Despite state claims to the contrary, case law over the last century supports an active federal role in wildlife management. The Supreme Court has ruled that Congress may enact legislation governing wildlife on federal lands. When conflicting state law exists, the supremacy clause ensures that federal legislation will prevail. Although the preceding cases do not specifically address fish-stocking and wilderness issues, current judicial interpretation of state and federal jurisdiction supports the direct involvement of federal wilderness managers in wildlife management decisions.

\section{Agency Regulations, Policies, AND AgreEMENTS}

The Supreme Court has clearly endorsed the federal government's right to enact and enforce wildlife management legislation, but it is up to Congress and the federal agencies to exercise this authority through law and policies. Wildlife management in wilderness is affected by the Wilderness Act and over 100 other laws that govern wildlife management in the four federal agencies (Musgrave and others 1998). In addition to these laws, agencies are administered through a two-tiered regulatory framework. After Congress enacts laws, the affected agencies must translate them into regulations and policies. Regulations are the highest regulatory level and are promulgated according to certain guidelines and subject to public comment. Regula- tions are legally binding after they are published in the Code of Federal Regulations. At the next regulatory level are policies that address specific aspects of an agency's management tasks. Although policies are not legally controlling, courts have found agencies at fault for ignoring them (Western Radio Services Co. Inc. v. Espy 1996; Meyer 1998).

\section{Regulations}

None of the agencies' regulations specifically address wilderness fish stocking, but the three USDI agencies are subject to departmental regulation that focuses on state and federal interactions over wildlife management (43 CFR Subtitle A Part 24 (10-198)). This regulation recognizes the dual authority of state and federal agencies and the need for cooperation between agencies. This regulation further outlines the constitutional basis for federal authority but reaffirms state management authority by stating:

The power of Congress respecting the taking of fish and wildlife has been exercised as a restrictive regulatory power, except in those situations where the taking of these resources is necessary to protect Federal property. With these exceptions, and despite the existence of constitutional power respecting fish and wildlife on Federally owned lands, Congress has, in fact, reaffirmed the basic responsibility and authority of the States to manage fish and resident wildlife on Federal land (section 24.3b).

Although this regulation recognizes the federal government's constitutional right to exercise wildlife management authority, it reaffirms the states' traditional role, effectively reinforcing the regulatory status quo. The regulations also state that even though Congress has charged the Secretary of Interior with specific responsibilities regarding certain fish and wildlife resources, "State jurisdiction remains concurrent with Federal authority" (section 24.3c). The USDA Forest Service regulations do not discuss either fish stocking or state wildlife jurisdiction.

In summary, although current regulations were written well after the Hughes Supreme Court's dismissal of Geer in 1979 and the courts have consistently ruled that federal agencies can be involved in decisions regarding wildlife on public lands, current federal wildlife regulations largely defer wildlife management responsibility to the states. This deference appears to stem more from traditional views than from constitutional or legislative necessity, supporting Matthews's (1986) contention that 
"with wildlife management, it is politics and not 'law' that controls which level of government is the manager."

\section{Policies}

Policies that guide wilderness management are found in the manuals for each agency, or in director's orders for the National Park Service (NPS). These policies discuss state and federal interactions and fish stocking in greater detail than the regulations.

The BLM and FS are the only agencies with wilderness policies that explicitly discuss state responsibilities for wildlife management. The BLM's policy section on management responsibility states that the Wilderness Act does not change the responsibilities of the states and the BLM relative to wildlife management, but the management activities of both agencies are equally constrained by provisions of the Act (USDI Bureau of Land Management 1983). The FS's policy recognizes that states have "jurisdiction and responsibilities for the protection and management of wildlife and fish populations in wilderness." The agency's policy is to cooperate with state authorities and base all management recommendations on the needs of the wilderness (USDA Forest Service 1990). However, for a variety of reasons (Bean 1978; Gottschalk 1978; Catton and Mighetto 1998), the agency often defers to the states.

Each agency has explicit policies on fish stocking in wilderness (USDI Bureau of Land Management 1983; USDI Fish and Wildlife Service 1986; USDI National Park Service 1988; USDA Forest Service 1990; USDI National Park Service 1999). Although some of these statements are under revision, we will discuss how these current polices address the following central issues.

Acceptability of fish stocking. The policies of all four agencies permit fish stocking in wilderness areas, although the reasons vary. Stocking of fish in NPS wilderness must be for the purpose of preserving or restoring "natural aquatic habitats and the natural abundance and distribution of native aquatic species." The policy of both the BLM and the FS is that fish-stocking programs must meet wilderness management objectives. FWS policy allows stocking to reestablish extirpated species and for the recovery of threatened and endangered species.

Restrictions on fish stocking. NPS policy prohibits stocking currently fishless waters, but the BLM and FS allow such stocking. According to the BLM, fishless waters may be stocked only if the wilderness management plan defines the desirability of this action and only after considering the scientific value of the waters. The FS policy provides similar direction for stocking fishless waters in wilderness. Both the BLM and FS permit managers to consider stocking currently unstocked waters with historical fish populations on a case-by-case basis, based upon the benefit to the wilderness visitor and the effects on wilderness conditions. The FWS has no similar policy restrictions for fish stocking.

The BLM and FS permit aerial stocking of fish in wilderness, but only when such a program was established prior to wilderness designation. Neither the NPS or FWS policies discuss the possibility of aerial stocking.

Prioritizing species for stocking. Each agency gives preference to some species over others. The BLM's policy favors stocking "native" species in waters that previously supported the species and gives primary consideration to threatened and endangered species. The FWS policy emphasizes the stocking of "extirpated native" species. The FS policy lists species that may be stocked in the following priority order: “(a) Federally listed threatened or endangered, indigenous species; (b) indigenous species; (c) threatened or endangered native species if species is likely to survive and spawn successfully; and (d) native species if the species is likely to survive and spawn successfully." The NPS policy is to stock only native species to reestablish them in their historic ranges.

The FS and NPS prohibit stocking "exotic" species in wilderness, whereas the BLM policy allows established programs of stocking exotic species to continue. The FWS permits the stocking of exotic species that are threatened or endangered, but only if the program is consistent with ongoing recovery efforts and will not adversely affect "endemic" species.

Different terminology is used by each agency to describe acceptable and unacceptable species for stocking. The terms "native" and "indigenous" are used similarly, as are the terms "nonnative" and "exotic," although these terms have very different meanings to scientists. However, only the Forest Service provides definitions within its policy. As a result, these crucial words in each agency's policy may have different meanings, leading to considerable confusion and misunderstanding.

Impairment of wilderness values. The BLM and FS fish-stocking policies both recommend fish stocking as a benefit to the wilderness visitor and recognize the probability of increased visitation to stocked waters. The policies instruct managers to consider the possible negative impacts of increased visitation on wilderness values when planning stocking pro- 
grams. FS policy also states that managers are to "provide an environment where the forces of natural selection and survival rather than human actions determine which and what numbers of wildlife species will exist." Neither FWS nor NPS policy discusses this possible impairment of wilderness values.

Cooperation with state agencies. Only BLM and FS policies explicitly discuss cooperation with state agencies. Both agency policies state that Memoranda of Understanding should be established with state agencies to establish a stocking policy for each wilderness where stocking is permitted.

In summary, agency policies generally support wilderness values and impose a variety of restrictions on when and where stocking may occur. Not unexpectedly, agency policies differ considerably from one another, and they do not clarify or resolve the difficult issues related to state and federal authority for fish stocking in wilderness.

\section{Agreements between Federal and} State Agencies

Rather than clarifying the jurisdictional debate, the body of judicial interpretation, regulation, and policy creates concurrent authority between state and federal agencies. This dual jurisdiction causes considerable confusion that is often remedied through formal agreements. Federal and state agencies can enter into Memoranda of Understanding that provide guidance to clarify their interactions. Frustration between state wildlife and federal wilderness managers over differing management goals in wilderness, lack of standardization in implementing federal wilderness regulations and policies, and differences in interpretation of the Wilderness Act all led to an agreement between the BLM and FS with the International Association of Fish and Wildlife Agencies (IAFWA) representing the states. This "Policies and guidelines for fish and wildlife management in wilderness and primitive areas" was adopted in 1976 (IAFWA 1976), substantially revised and formally accepted by the BLM and FS in 1986 (USDA Forest Service 1986; USDI Bureau of Land Management 1986), and reaffirmed in 1995 with a letter signed by the chief of the FS, the director of the BLM, and the executive vice president of IAFWA (USDA Forest Service 1995). Although state compliance with this agreement is voluntary, most state wildlife agencies in the western United States have established formal Memoranda of Understanding with the BLM and FS based on the 1986 IAFWA policies and guidelines.

The primary purpose of the IAFWA agreement is to promote and guide improved cooperation and coordination between state and federal managers, stating that "both state and federal agencies are responsible for fostering mutual understanding and cooperation in the management of fish and wildlife in wilderness" and that "these guidelines should serve as a framework for cooperation." The IAFWA agreement also provides specific guidance to state and federal interactions over fish stocking in wilderness. Several authors have pointed out aspects of IAFWA guidance that are ambiguous and could be improved (for example, Hoover 1978; Duff 1995; Fraley 1996), but in general, the language of the Wilderness Act and wilderness values are supported within the context of seeking mutual agreement between state and federal managers.

In summary, the IAFWA agreement between state and federal agencies provides a useful framework for cooperation and coordination related to fish stocking. However, some ambiguous definitions (Fraley 1996) and issues not envisioned by the agreement, such as the effects of fish stocking on native biological diversity, warrant revising this pivotal document. There were discussions between federal agencies and several states about revising the IAFWA agreement throughout the 1990s (D. Duff personal communication), but they have yet to produce a new agreement. Within the IAFWA agreement, the burden of responsibility remains with individuals, within their respective agencies to seek mutual agreement. This individual responsibility can promote improved cooperation and coordination. Individuals, however, can also engage in "we know better than they do" attitudes, leading to increased controversy and conflict. Strong leadership is needed at all administrative levels to support and fulfill the cooperative fisheries and wilderness goals of the IAFWA agreement.

\section{Conclusions}

Untangling the problems caused by concurrent federal and state authority requires an understanding of the origin of traditional states rights views, historical and current judicial interpretation, and agency regulations and policies. Unfortunately, these all seem to point in different directions: federal legislation supports concurrent state and federal authority, judicial interpretation clearly supports federal involvement in wildlife management decisions in wilderness, federal agency regulations and policies largely support a traditional states rights view, and the IAFWA agreement strongly supports wilderness values and asserts the need for cooperation between state and federal agencies.

Fish stocking does compromise certain wilder- 
ness values, and wilderness designation does impose restrictions on the types of wildlife management actions that are appropriate in wilderness areas. In some cases, these compromises and restrictions have led to an "either/or" dichotomous view that pits state fish stocking programs against federal responsibility for protecting wilderness values. Differences in agency missions, traditions, and cultures also tend to exacerbate "us vs them" attitudes. Examining state and federal interactions over fish stocking in wilderness, Fraley (1996), for example, concluded that agency personnel need to "rise above the bureaucracy and egos, work together, and share responsibility for managing all wilderness resources." In these cases, managers need to be reminded that "it is not a question of what level of government shall have the basic authority but, rather, how a shared authority can be made most productive" (Gottschalk 1978).

Fortunately, divisive attitudes are giving way to better understanding, communication, and cooperation in the face of extraordinarily complex social and ecological problems. Cooperation among state and federal managers will be increasingly important as research continues to reveal subtle and complex ecological interactions between stocked fish and native aquatic biota (see the other papers in this special feature). Changing social values and ecological complexities guarantee that what works in one area may not work in other areas, and that well developed and persistent communication and cooperation between state and federal managers will be necessary in crafting effective management solutions on a case-by-case basis.

Backed by Supreme Court decisions, federal managers can be involved in wildlife management decisions to defend wilderness values. Continuing to improve communication and cooperation between state and federal managers will ensure that wilderness contributes to the protection and preservation of wildlife, just as wildlife contributes to the value of wilderness.

\section{ACKNOWLEDGMENTS}

We thank Len Broberg, Dale Burkett, Ann Carlson, Steve Corn, Tom Flowers, Mark Hudy, Roland Knapp, George Nickas, Dave Parsons, Kelly Russell, Daniel Schneider, Linda Ulmer, and Bill Worf for comments on the manuscript that helped to clarify and focus our thoughts. The in-depth and insightful comments from Glen Contreras and Don Duff are especially appreciated.

\section{REFERENCES}

Aderhold M. 1979. The knotty issue of wildlife jurisdiction. Montana Outdoors 10(2):15-9.

Aplet GH. 1999. On the nature of wildness: exploring what wilderness really protects. Denver Univ Law Revie 76:347-67.

Bahls P. 1992. The status of fish populations and management of high mountain lakes in the western United States. Northwest Sci 66:183-93.

Bean MJ. 1978. Federal wildlife law. In: Brokaw HP, editor. Wildlife and America: contributions to an understanding of American wildlife and its conservation. Council on Environmental Quality. Washington (DC): US Government Printing Office. p 279-89.

Bean MJ, Rowland MJ. 1997. The evolution of national wildlife law. 3rd ed. Westport (CT): Praeger.

Buono F. 1997. Managing wildlife in the parks: the legal basis. George Right Forum 14:19-24.

Carter D. 1996. Maintaining wildlife naturalness in wilderness. Int J Wilderness 3(3):17-21.

Catton T, Mighetto L. 1998. The fish and wildlife job on the national forests: a century of game and fish conservation, habitat protection, and ecosystem management. Washington (DC): USDA Forest Service.

Coggins GC. 1980. Wildlife and the Constitution: the walls come tumbling down. Washington Law Rev 55:295-358.

Coggins GC, Ward ME. 1981. The law of wildlife management on the federal public lands. Oregon Law Rev 60:59-155.

Cole DN. 2000. Paradox of the primeval: ecological restoration in wilderness. Ecol Restor 18:77-86.

Cordell HK, Tarrant MA, McDonald BL, Bergstrom JC. 1998. How the public views wilderness. Int J Wilderness 4(3):28-31.

Dawson CP, Tanger-Foster J, Friese GT, Carpenter J. 1998. Defining characteristics of U.S.A. wilderness experience programs. Int J Wilderness 4(3):22-7.

Duff DA. 1995. Fish stocking in U.S. federal wilderness areas: challenges and opportunities. Int J Wilderness 1(1):17-19.

Fraley J. 1996. Cooperation and controversy in wilderness fisheries management. Fisheries 21:16-21.

Geer v. Connecticut. 1896. 161 U.S. 519.

Gottschalk JS. 1978. The state-federal partnership in wildlife conservation. In: Brokaw HP, editor. Wildlife and America: contributions to an understanding of American wildlife and its conservation. Washington (DC): p 290-301. Council on Environmental Quality, US Government Printing Office.

Hoffman RL, Pilliod DS, editors. 1999. The ecological effects of fish stocking on amphibian populations in high-mountain wilderness lakes. Final report. Corvallis (OR): USGS/BRD Forest and Rangeland Ecosystem Science Center.

Hoover RL. 1978. IAFWA wilderness policy: state wildlife agency views. Trans North Am Wildlife Natl Resources Conf 43:37280.

Hughes v. Oklahoma. 1979. 441 U.S 322.

Hunt v. United States. 1928. 278 U.S. 96, 49 S. Ct. 38, 73 L. Ed. 200.

[IAFWA] International Association of Fish and Wildlife Agencies. 1976. Policies and guidelines for fish and wildlife management in wilderness and primitive areas. Proc Int Assoc Fish Wildlife Agencies 66:188-95.

Janzen D. 1998. Gardenification of wildland nature and the human footprint. Science 279:1312-3. 
Kleppe v. New Mexico. 1976. 426 U.S. 529, 49 L. Ed. 2d 34.

Landres PB. 1992. Temporal scale perspectives in managing biological diversity. Trans North Am Wildlife Natl Resources Conference 57:292-307.

Landres P, Meyer S. 1998. National Wilderness Preservation System database: key attributes and trends, 1964 through 1998. USDA Forest Service general technical report RMRSGTR-18. Ft. Collins (CO): Rocky Mountain Research Station.

Landres PB, Morgan P, Swanson FJ. 1999. Overview of the use of natural variability concepts in managing ecological systems. Ecol Appl 9:1179-88.

Liss WJ, Larson GL. 1991. Ecological effects of stocked trout on North Cascades naturally fishless lakes. Park Sci 11 (Summer): 22-3.

Liss WJ, Larson GL, Tyler T, Ganio L, Hoffman R, Deimling EA, Lomnicky G, McIntire CD, Truitt R. 1999. Ecological effects of stocked trout in naturally fishless high mountain lakes: North Cascades: National Park Service Complex, WA, USA. Phase II technical report NPS/CCSOOSU/NRTR-98-01. Washington (DC): National Park Service.

Loomis J, Echohawk JC. 1999. Using GIS to identify underrepresented ecosystems in the National Wilderness Preservation System in the USA. Environ Conserv 26:53-8.

Manning RE, Valliere WA. 1996. Environmental values, environmental ethics, and wilderness management. Int J Wilderness 2(2):27-32.

Matthews OP. 1986. Who owns wildlife? Wildlife Soc Bull 14: 459-64.

Meyer SM. 1998. Wilderness airstrips: a case study for using legislative history to inform wilderness management [thesis]. Missoula (MT): Department of Environmental Studies, University of Montana.

Missouri v. Holland. 1920. 252 U.S. 416, 434, 40 S. Ct. 382, 384, 64 L.Ed. 641.

Murray MP. 1994. Reconsidering fish stocking of high wilderness lakes. Wild Earth (Fall):50-2.

Musgrave RS, Flynn-O'Brien JA, Lambert PA, Smith AA, Marinakis YD. 1998. Federal wildlife laws handbook with related laws. Rockville (MD): Government Institutes.
Payne C, Bowker JM, Reed PC., editors. 1992. The economic value of wilderness. USDA Forest Service general technical report SE-78. Ashville (NC): Southeastern Forest Experiment Station.

Rolston H. 1994. Conserving natural value. New York: Columbia University Press.

Schoenfeld CA, Hendee JC. 1978. Wildlife management in wilderness. Pacific Grove (CA): Boxwood Press.

Turner J. 1996. The abstract wild. Tucson (AZ): University of Arizona Press.

US Code of Federal Regulations. 1998. Title 43, Subtitle A, Part 24. October 1, 1998.

USDA Forest Service. 1986. Interim directive no. 2 to the wilderness management handbook. Section 2309.19.

USDA Forest Service. 1990. FS manual title 2300-recreation, wilderness, and related resource management. Section 2323.32-1. June 21, 1990.

USDA Forest Service. 1995. Fisheries and wildlife management in wilderness. Letter (March 8, 1995) from the chief of the Forest Service to the regional foresters.

USDI Bureau of Land Management. 1983. BLM manual section $8560-$ management of wilderness areas. Section 34.A.2. April 27, 1983.

USDI Bureau of Land Management. 1986. Policies and guidelines for fish and wildlife management in wilderness areas. Instruction memorandum no. 86-665.

USDI Fish and Wildlife Service. 1986. FWS refuge manual 6 RM 8-wilderness area management. May 8, 1986.

USDI National Park Service. 1988. Management policies, biological resource management. Chapter 4:8.

USDI National Park Service. 1999. Directors orders no. 41. August 2, 1999.

Western Radio Services Co. Inc. v. Espy. 1996. 79 F 3d 896 (9th Circ.).

Zahniser E. 1992. Where wilderness preservation began: Adirondack writings of Howard Zahniser. Utica (NY): North Country Books.

Zahniser H. 1956. The need for wilderness areas. Living Wilderness Winter-Spring 59:37-43. 